\title{
М.І. Мураль
}

\section{НОВІ ЗНАХІДКИ НИЖНЬОЮРСЬКИХ БЕЛЕМНІТІВ У ПЕНІНСЬКІЙ ЗОНІ УКРАЇНСЬКИХ КАРПАТ}

\section{M.I. Mural}

\section{NEW FINDINGS LOWER JURASSIC BELEMNITES IN PENNINE ZONE OF THE UKRAINIAN CARPATHIANS}

Детально описані нові знахідки п'яти видів лейясових белемнітів: Passaloteuthis apicicurvata Blainville, Passaloteuthis paxillosus Schlotheim, Mesoteuthis tripartita Schlotheim, Mesoteuthis triscissa Janensch, Salpingoteuthis tubularis Young et Bird. Вони знайдені вперше в північно-західній частині Пенінської зони - в Перечинському і Новоселицькому кар'єрах. Раніше ці види були знайдені тільки в крайній південносхідній частині Українських Карпат.

Ключові слова: нижня юра, Пенінська зона, белемніти, ростр, альвеола.

Подробно описаны новые находки пяти видов лейясових белемнитов: Passaloteuthis apicicurvata Blainville, Passaloteuthis paxillosus Schlotheim, Mesoteuthis tripartita Schlotheim, Mesoteuthis triscissa Janensch, Salpingoteuthis tubularis Young et Bird. Они обнаружены впервые в северо-западной части Пенинской зоны - в Перечинском и Новоселовском карьерах. Ранее эти виды были найдены только в крайней юго-восточной части Украинских Карпат.

Ключевые слова: нижняя юра, Пенинская зона, белемниты, ростр, альвеола.

This paper details the new finds 5 types liasian belemnites: Passaloteuthis apicicurvata Blainville, Passaloteuthis paxillosus Schlotheim, Mesoteuthis tripartita Schlotheim, Mesoteuthis triscissa Janensch, Salpingoteuthis tubularis Young et Bird. They first discovered in the north-western part of the structural-tectonic units in Perechyns and Novoselytsya quarry. These species were found only in the south-eastern part of the Ukrainian Carpathians.

Key words: lower jurassic, Piennine zone, belemnites, rostr, alveola.

\section{ВСТУП}

Як відомо, у будові Флішевих Карпат виділяються три основні структурно-тектонічні зони - Скибова, ЧорногорськоДуклянсько-Кросненська, Рахівська, а у Внутрішніх - Пенінська, Мармароська зони, Мармароський кристалічний масив і Закарпатський прогин. Виникненню цих вузьких, витягнутих вздовж загальнокарпатського простягання структурно-фаціальних одиниць передував поділ дна глибоководного моря на окремі, порівняно вузькі, коритоподібні басейни такої ж орієнтації. Вони характеризувалися деякою мірою різним тектонічним режимом і палеогеографічними умовами, завдяки чому одновікові відклади тут літологічно (тією чи іншою мірою) різняться між собою і містять рештки відмінної між собою палеобіоти. Юрські відклади відіграють суттєву роль в геологічній будові Пенінської зони. Вони тут найпоширеніші в Українських Карпатах. Та незважаючи на їх значне поширення і майже півторастолітню історію досліджень, детальне стратигра- фічне розчленування юри ускладнювалося через складну геологічну будову регіону, недостатність або повну відсутність у значній частині відкладів палеонтологічних решток при загальній незадовільній збереженості і слабкій вивченості останніх.

Через відсутність палеонтологічного обгрунтування віку частину виходів юрських утворень відносили до молодших або старших відкладів. Це нерідко призводило до помилкових тектонічних і структурних побудов, а часто, після єдиної фрауністичної знахідки, замість великих антикліноріїв чи синкліноріїв на картах з'являлися пологі покриви чи інші, протилежні зображеним раніше, структури.

\section{МАТЕРІАЛИ ТА МЕТОДИ}

В процесі польових досліджень у різних місцях Пенінської зони Українських Карпат (Новоселицькому, Перечинському, Приборжавському кар'єрах та на інших відслоненнях) нами було зібрано колекцію юрських белемнітів, яка представле- 
на у кількості понад 1000 екземплярів. У цій структурно-тектонічній одиниці белемніти приурочені головним чином до глинистих фацій, в яких, крім них, інші палеорештки дуже рідкісні або цілком відсутні. Враховуючи той фракт, що після амонітів, белемніти $є$ другою ортостратиграфрічною групою для встановлення відносного геологічного віку, стратифікації і кореляції юрських розрізів, в цій публікації подається опис та зображення п'яти видів белемнітів: Passaloteuthis apicicurvata Blainville, Passaloteuthis paxillosus Schlotheim, Mesoteuthis tripartita Schlotheim, Mesoteuthis triscissa Janensch, Salpingoteuthis tubularis Young et Bird, вперше виявлених в північно-західній частині Українських Карпат - Новоселицькому і Перечинському кар'єрах.

\section{РЕЗУЛЬТАТИ ТА ЇХ ОБГОВОРЕННЯ \\ Тип MOLLUSCA \\ Клас CEPHALOPODA \\ Підклас ENDOCOCHLIA \\ Ряд DECAPODA \\ Підряд BELEMNOIDEA Naef, 1912 \\ Родина BELEMNITIDAE Orbigny, 1845 \\ Підродина PASSALOTEUTHINAE Naef, 1922}

Рід PASSALOTEUTHIS Lissajous, 1915

Passaloteuthis apicicurvata Blainville,1827

Таблиця I, фріг. 1, а-е.

1947 Passaloteuthis apicicurvata Blainville:

Крымгольц, с. 198, табл. 39, фриг. 3 а, в.

1968 Passaloteuthis apicicurvata Blainville:

Круглов, Гаврилишин, Кримгольц, стор. 89.

1972 Passaloteuthis apicicurvata Blainville:

Гаврилишин, Круглов, № 9 с. 39, табл. І, фиг. 4 а-в.

1981 Passaloteuthis apicicurvata Blainville: Парышев, Никитин, с. 77, табл. 41, фиг. 5 a-B.

Опис. Ростр дуже доброї збереженості і достатньо масивний. Про загальну форму ростру можна сказати таке: верхня частина циліндрична, а нижня - конічна. Вістря різко зміщене до спинної сторони. На вістрі дуже чіткі спинно-бокові борозни, які простежуються на третину ростру. Окрім них, можна відзначити дві слабо виражені черевні борозни та ще менше виражену (?) спинну. Для ростру характерне стиснення з боків, причому у верхній частині чітке, а в нижній - форма ростру фактично кругла.
Поперечний переріз (незважаючи на деякі механічні пошкодження) виразно овальної форми. Альвеола сягає третини ростру.

\begin{tabular}{|c|c|c|c|}
\hline \multicolumn{4}{|c|}{ Розміри, мм* : } \\
\hline$R$ & DV & LL & Pa \\
\hline $116(552)$ & $21(100)$ & $20(95)$ & $78(371)$ \\
\hline
\end{tabular}

*Тут і далі: R - довжина ростру; DV - спинно-черевний (дорзовентральний) діаметр; LL - боковий (латеральний) діаметр; Ра - довжина постальвеолярної частини.

Місцезнаходження. Українські Карпати, Пенінська зона, Новоселицький, Приборжавський кар'єри.

Стратиграфрічне та географрічне поширення. Середній лейас. Північний Кавказ, Німеччина, Англія, Румунія.

Passaloteuthis cf. paxillosus Schlotheim, 1813 Таблиця. I, фріг. 2, а-ट.

1968 Passaloteuthis paxillosus Schlotheim: Круглов, Гаврилишин, Кримгольц, с. 89.

1972 Passaloteuthis paxillosus Schlotheim: Гаврилишин Круглов, с. 38, табл. І, фиг. 3 a-г.

1981 Passaloteuthis paxillosus Schlotheim: Парышев, Никитин, с. 78, табл. 41, фиг. 6 a-r.

Опис. Ростр погано збережений, імовірно середніх розмірів (оскільки збережений фрагмент ростру від вістря до початку альвеоли). Сама форма ростру - циліндрична. Закінчення ростру дещо пошкоджене, але 3 усього можна стверджувати, що нижня частина ростру поступово переходить у вістря. Саме вістря трохи зміщене до спинної сторони, i, як результат, нижня частина черевної сторони різкіше заокруглюється.

Незважаючи на розшарування вістря можна простежити сліди спинно-бокових борозн, які фрактично присутні лише на вістрі. Поперечний переріз (в частині СБ) округлої форми. Альвеола зміщена до черевної сторони. В цілому, черевна частина дещо вужча за спинну і відповідно тонша.

\begin{tabular}{|c|c|c|c|}
\hline \multicolumn{4}{|c|}{ Розміри, мм: } \\
\hline R & DV & LL & Pa \\
\hline $63(325)$ & $19,4(100)$ & $19(98)$ & $59(304)$ \\
\hline
\end{tabular}

Місцезнаходження. Українські Карпати, Пенінська зона, Новоселицький кар'єр. 

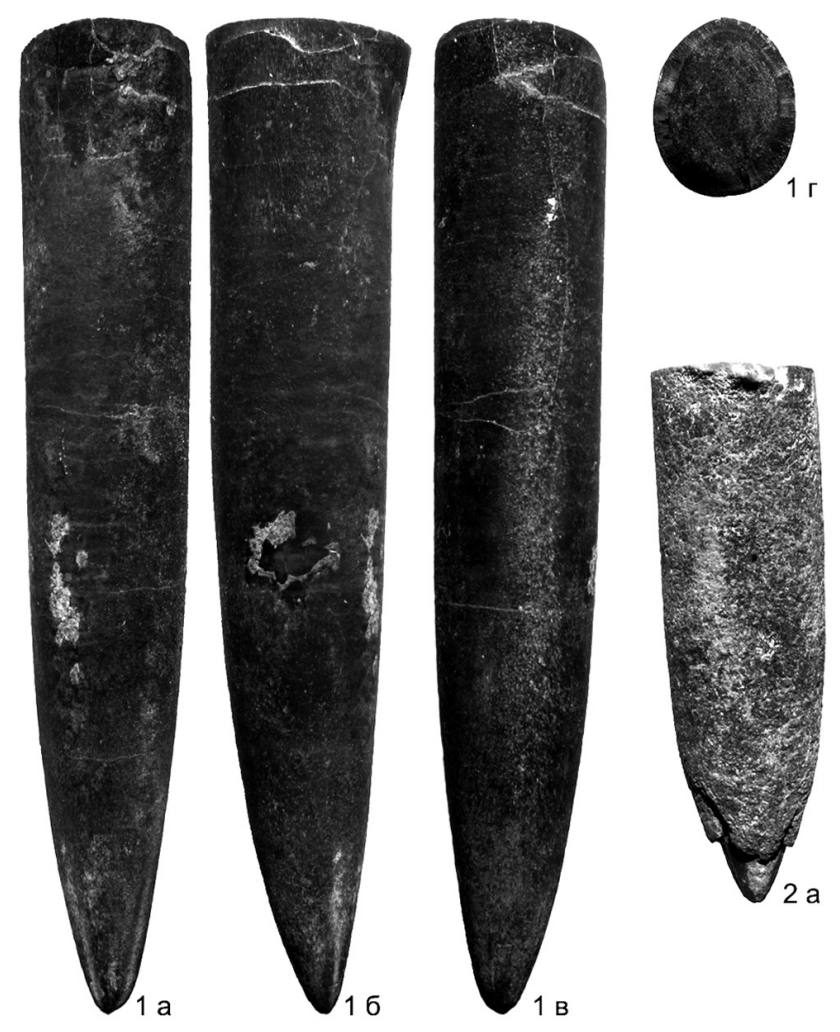

Таблиця І. Ранньоюрські белемніти Пенінської зони Українських Карпат
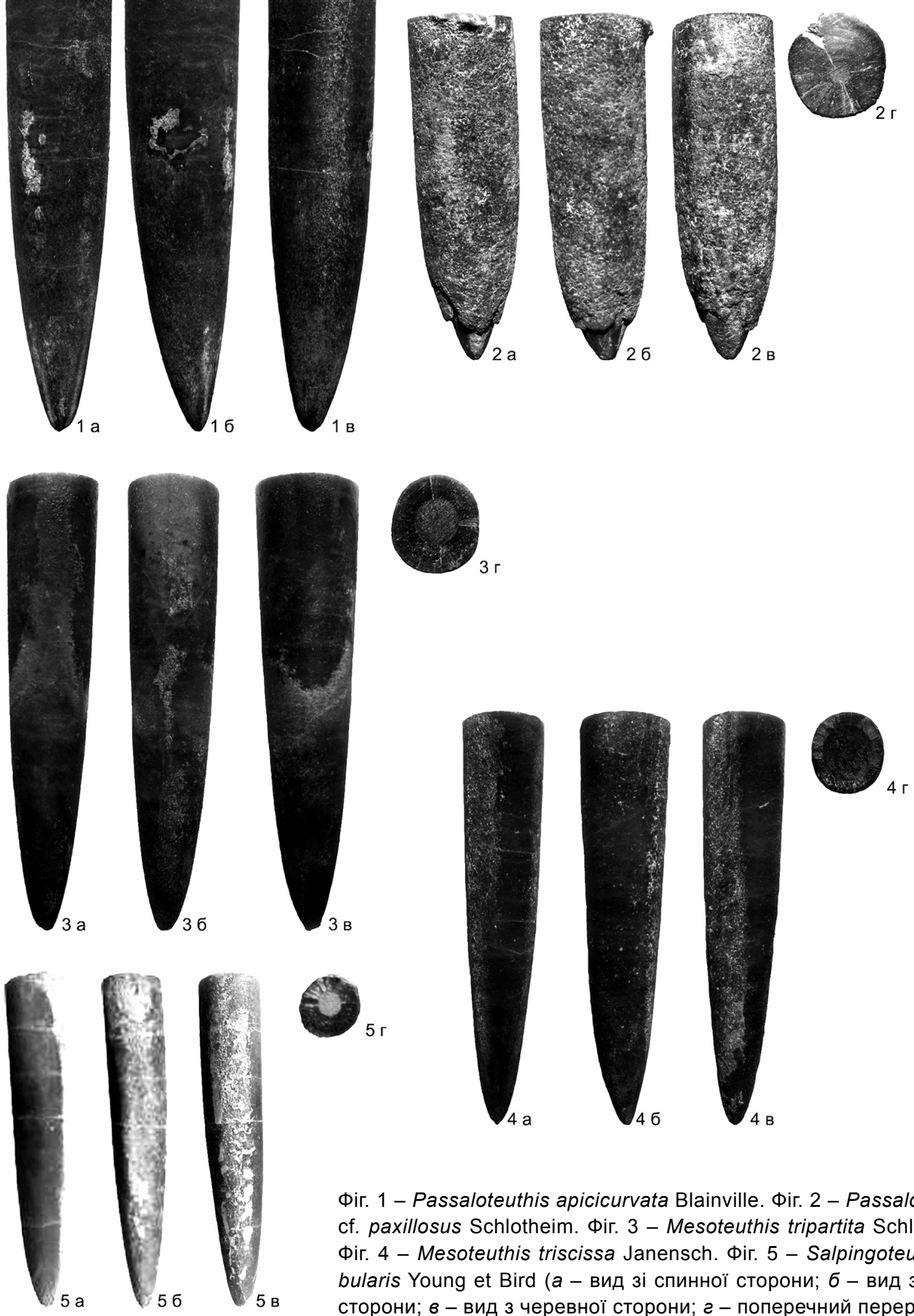
$5 r$ 
Стратиграфрічне та географрічне поширення. Тоар-аален. Північний Кавказ, верхній тоар, північно-західна окраїна Донбасу, Франція, Німеччина, Румунія.

Рід MESOTEUTHIS Lissajous, 1915

Mesoteuthis tripartita Schlotheim, 1820

Таблиця I, фріг. 3, а-е.

1947 Mesoteuthis tripartita Schlotheim: Крымгольц, с. 201, табл. 40, фиг. 1 a-c.

1968 Mesoteuthis tripartita Schlotheim:

Круглов, Гаврилишин, Кримгольц, с. 87-89.

1972 Mesoteuthis tripartita Schlotheim: Гаврилишин, Круглов, с. 40, табл. II, фиг. 3, 4.

1981 Mesoteuthis tripartita Schlotheim: Парышев, Никитин, с. 82, табл. 42, фриг. 2 a-в.

Опис. Ростр достатньо добре збережений, середніх розмірів, має фоорму витягнутого конуса (субконічну фрорму). Ростр поступово переходить у вістря. Саме вістря розміщене дещо ексцентрично, зі зміщенням до спинної сторони. На вістрі чітко виражені дві спинно-бокові борозни, які ближче до альвеолярної частини міліють на бокових сторонах ростру. На бокових сторонах виразна пласкатість, від чого поперечний переріз - округло-чотирикутний. Альвеола розміщена трішки ексцентрично (зі зміщенням до черевної сторони) і займає близько третини ростру.

\begin{tabular}{|c|c|c|c|}
\hline \multicolumn{4}{|c|}{ Розміри, мм } \\
\hline $\mathrm{R}$ & $\mathrm{DV}$ & $\mathrm{LL}$ & $\mathrm{Pa}$ \\
\hline $83(461)$ & $18(100)$ & $16(88)$ & $64(356)$ \\
\hline
\end{tabular}

Місцезнаходження.

Українські Карпати, Пенінська зона, Новоселицький, Перечинський кар'єри.

Стратиграфрічне та географічне поширення: Тоар-аален. Північний Кавказ, верхній тоар, північно-західна окраїна Донбасу, Франція, Німеччина, Румунія.

Mesoteuthis triscissa Janensch, 1902 Таблиця I, фріг. 4, а-е.

1931 Mesoteuthis triscissa Janensch: Крымгольц, с. 12, табл. 1, фриг. 4, 5.

1947 Mesoteuthis triscissa Janensch: Крымгольц, с. 201, табл. 40, фииг. 2 а-в.

1968 Mesoteuthis triscissa Janensch: Круглов, Гаврилишин, Кримгольц, с. 88.
1972 Mesoteuthis triscissa Janensch: Гаврилишин, Круглов, с. 41, табл. III, фииг. 1 a-в.

1981 Mesoteuthis triscissa Janensch: Парышев, Никитин, с. 82, табл. 44, фриг. 1 a-B.

Опис. Два ростри середньої величини, хорошої збереженості. Форма рострів, як i в попереднього виду, має вигляд витягнутого конуса (або ж субконічну форму). Вістря зміщене до спинної сторони і, на відміну від попереднього виду, більш витягнуте (загострене). Від вістря на третину від задньої поставеолярної частини виражені чіткі спинно-бокові борозни, а на одному екземплярі можна простежити слабо виражену черевну борозенку. Форма поперечного перерізу овальна. Стиснення з боків ростру спостерігається практично по всій довжині. Альвеола займає близько третини ростру, ексцентрична зі зміщенням до черевної сторони.

\begin{tabular}{|c|c|c|c|}
\hline \multicolumn{4}{|c|}{ Розміри, мм } \\
\hline R & DV & LL & Pa \\
\hline $75(483)$ & $15(100)$ & $14(93)$ & $55(399)$ \\
\hline
\end{tabular}

Місцезнаходження. Українські Карпати, Пенінська зона, Новоселицький, Перечинський кар'єри.

Стратиграфрічне та географрічне поширення. Тоар. Північний Кавказ, верхній тоар північно-західної окраїни Донбасу, Франція, Німеччина, Румунія.

Порівняння. Mesoteuthis triscissa Janensch відрізняється від подібного йому Mesoteuthis tripartita Schlotheim формою поперечного перерізу, більш загостреним вістрям (від цього, очевидно, вістря більш чіткіше зміщене до спинної сторони) та більш вираженою пласкатістю бічних сторін. Також спинно-бокові борозни в останнього дещо слабше виражені.

Рід SALPINGOTEUTHIS Lissajous, 1915 Salpingoteuthis tubularis Young et Bird, 1822

Таблиця I, фріг. 5, а-е.

1968 Salpingoteuthis tubularis Young et Bird: Круглов, Гаврилишин, Кримгольц, c. 87.

1972 Salpingoteuthis tubularis Young et Bird: Гаврилишин, Круглов, с. 38, табл. I, фиг. 2 а-г. 
1981 Salpingoteuthis tubularis Young et Bird: Парышев, Никитин, с. 77, табл. 41, фриг. 4 а-г.

Опис. Ростри достатньо хорошої збереженості, тонкі субконічної форми (поступово і достатньо рівномірно звужуються до закінчення ростру). На одному з екземплярів спинно-бокові борозни слабо виражені, а на другому - достатньо добре і простежуються на третину ростру. Поперечний переріз овальної форми. Альвеола коротка і незначною мірою зміщена до черевної сторони, звідси спинна сторона товстіша за черевну. На бічних сторонах видна чітка пласкатість, але лише в альвеолярній частині ростру.

\begin{tabular}{|c|c|c|c|}
\hline \multicolumn{4}{|c|}{ Розміри, мм } \\
\hline $\mathrm{R}$ & $\mathrm{DV}$ & $\mathrm{LL}$ & $\mathrm{Pa}$ \\
\hline $61(517)$ & $11,8(100)$ & $11,1(94)$ & $53(449)$ \\
\hline
\end{tabular}

Місцезнаходження. Українські Карпати, Пенінська зона, Новоселицький, Приборжавський кар'єри.

Стратиграфічне та географічне поширення. Тоар-аален. Західна Європа.

\section{ВИСНОВКИ}

Розташування Українських Карпат між Західними і Південними Карпатами, а також відсутність детального монографічного вивичення однієї з найважливіших для стратиграфрічного розчленування юрських відкладів групи палеоорганізмів - белемнітів, визначило особливо гостру актуальність проблеми детального палеонтолого-стратиграфрічного вивчення відкладів Пенінської зони.

Вирішення цієї актуальної проблеми має також і пряме прикладне значення, оскільки в одновікових відкладах Передкарпатського прогину та інших регіонах юрські утворен- ня вміщують промислові скупчення нафти і газу.

Впродовж останніх років у процесі польових досліджень мені вдалось зібрати колекцію белемнітів, що належать до ортостратиграфічної групи палеоорганізмів, за якими проводиться детальне стратиграфрічне розчленування та кореляція юрських розрізів, а також встановлення відносного геологічного віку. Таким чином, виявлені нами белемніти у різних типах порід, часто в тих, де інші рештки палеофауни не трапляються, слугують суттєвим доповненням та уточненням стратиграфрічної схеми, розробленої (Г.І. Гоцанюк, Р.Й. Лещух) для юрських відкладів Пенінської зони за амонітами.

1. Атлас руководящих форм ископаемых фраун СССР. - М., 1949.

2. Гаврилишин В.И., Круглов С.С. Юрские белемниты зоны Пеннинских утесов (Закарпатье) // Палеонтол. сб. - 1972. - № 9. - С. 36-43.

3. Густомесов В.A. О фррагмоконе рода Belemnella // Палеонтол. журн. - 1980. - № 1. - С. 72-77.

4. Густомесов В.А. К ревизии юрских белемнитов // Бюл. Моск. о-ва испытателей природы. Отд. геол. - 1977. - Т. 52, вып. 2. - С.103-117.

5. Круглов С.С., Гаврилишин В.І., Кримгольи Г.Я. Нові дані про стратиграфрію юрських відкладів околиць с. Приборжавське в зоні пенінських скель Закарпаття // Геол. журн. - 1968.- № 4. - С. 86-90.

6. Крымгольи Г.Я. Методика определения мезозойских головоногих. - Л: Изд-во Ленингр. ун-та, 1960. - 89 c.

7. Крымгольи Г.Я. Юрские белемниты Крыма и Кавказа. - М.; Л., 1931. - 53 с.

8. Основы палеонтологии. Моллюски - головоногие / Под ред. Ю.А. Орлова. - М., 1958. - Т. 6. - 358 с.

9. Парышев А.В., Никитин И.И. Головоногие моллюски юры Украины. - Киев: Наук. думка, 1981. -142 c.

Львівський національний університет імені Івана Франка, Львів

E-mail: mmural@ukr.net 